\title{
Environmental Concern, Attitude and Responsibility and Green Purchasing Behaviour of Consumers in Madurai District
}

\begin{abstract}
Large number of problems related to environment experienced by consumers is the main reason for them to move from conventional or non green purchasing to green purchasing and green products reduce harmful impacts on environment and society. Significant difference prevails amongst environmental concern, environmental attitude and environmental responsibility and socio-economic profile of consumers. Environmental concern, environmental attitude and environmental responsibility have positive, moderate and significant relation with green purchasing behaviour of consumers. Therefore, consumers must live harmoniously with natural environment and they should not make any attempts to modify character of environment and consumers must enthusiastically involve in conservation of environment. Further, Government and environmental organizations and non government organizations should make consumers to realize their responsibilities and necessity for protection of environment through various awareness programmes and campaigns and incentives.
\end{abstract}

S. Rani

Keywords- Attitude, Concern, Environment, Green Purchasing Behaviour, Responsibility

\section{INTRODUCTION}

Currently, all the nations across the globe are worrying about environmental problems namely global warming, environmental pollution and degradation, climate change and depletion of environmental resources (Atthirawong and Panprung, 2017). Nowadays, consumers are also having higher degree of apprehension on changes in environment in comparison with past years and their purchasing behaviour are also remarkably changed (Papadopoulos et al 2010). Consumers are giving importance to environmental problems in purchasing and consuming various products (Hessami and Yousefi, 2013). Purchasing and consumption behaviour of consumers have significant impact on environment (Wahid et al 2011) and of the gravity of environmental problems, thus, consumers are more environmentally conscious (Han et al 2009).

Large number of problems related to environment experienced by consumers is the main reason for them to move from conventional or non green purchasing to green purchasing (Dagher and Itani, 2012) and green products reduce harmful impacts on environment and society (Cornelissen et al 2008). Presently, substantial quantum of consumers purchase green products which create very less damage to environment, consuming low level of energy and

Revised Manuscript Received on December 16, 2019.

*Dr. S. RANI, Department of Commerce, Kalasalingam Academy of Research and Education, Krishnankoil, India. Email:rani.s@klu.ac.in friendly with environment. Thus, it is important to study environmental concern, attitude and responsibility and green purchasing behaviour of consumers in Madurai district.

\section{REVIEW OF LITERATURE}

Rahbar and Wahid (2011) found that knowledge, concern and attitude on environment and advertisements had significant effect on purchasing of green products amongst consumers. Aman et al (2012) concluded that environmental concern and knowledge were influencing green purchasing intention of consumers which was mediated by attitude of consumers on environment.

Molina et al (2013) revealed that environmental knowledge, environmental attitude and environmental consciousness were directly related to purchasing behaviour of students. Lee et al (2014) indicated that knowledge, attitude and concern on environment had positive and significant influence on green purchasing amongst consumers.

Dagher et al (2015) showed that concern and attitude on environment had positive and significant impact on green purchasing behaviour of consumers. Jamal et al (2016) found that attitude and awareness about environment, knowledge and peer groups were influencing green purchasing behaviour amongst consumers.

Maichum et al (2017) concluded that environmental concern and attitude were significantly and positively influencing green purchasing intention of young consumers. Kusuma and Handayani (2018) revealed that knowledge on environment, attitude on environment and green advertisements had positive and significant impact on green purchase intention of consumers. Ting et al (2019) found that attitude on environment, behavioural control, expected emotions were positively and significantly related with green purchasing behaviour of consumers.

\section{OBJECTIVES OF THE STUDY}

A. To examine environmental concern, attitude and responsibility of consumers.

B. To scrutinize difference amongst environmental concern, attitude and responsibility and socio-economic profile of consumers.

C. To study relation amongst environmental concern, attitude and responsibility and green purchasing behaviour of consumers. 


\section{HYPOTHESES OF THE STUDY}

A. There is no significant difference in environmental concern, attitude and responsibility amongst socio-economic profile of consumers.

B. There is no significant relation amongst environmental concern, attitude and responsibility and green purchasing behaviour of consumers.

\section{METHODOLOGY}

The present study is carried out in Madurai district. Consumers of green purchasing are chosen by using simple random sampling method and questionnaire method is used to gather data from 300 consumers of green purchasing. Percentages are computed to understand socio-economic profile of consumers and mean and standard deviation are worked out to know agreement level of consumers for environmental concern, attitude and responsibility. t-test and F-test are used to scrutinize difference amongst socio-economic profile of consumers and environmental concern, attitude and responsibility. Correlation analysis is used to study relation amongst environmental concern, attitude and responsibility and green purchasing behaviour of consumers.

\section{RESULTS AND DISCUSSION}

\section{A. SOCIO-ECONOMIC PROFILE OF CONSUMERS}

The socio-economic profile of consumers is given in Table-1. The findings disclose that 59.67 per cent of them are males, whereas, 40.33 per cent of them are females and 33.00 per cent of them fall under age category of $36-45$ years, whereas, 5.67 per cent of them fall under age category of below 25 years. The findings elucidate that 32.00 per cent of them possess under graduation, whereas, 10.00 per cent of them possess secondary education and 27.33 per cent of them earn monthly income of Rs.25,001 - Rs.35,000, whereas 22.67 per cent of them earn monthly income of More than Rs.45,000. The findings clarify that and 70.00 per cent of them are married, whereas, 30.00 per cent of them are unmarried and 79.67 per cent of them have nuclear family, whereas, 20.33 per cent of them have joint family.

Table-1. Socio-Economic Profile of Consumers

\begin{tabular}{|l|l|l|}
\hline $\begin{array}{l}\text { Socio-Economic } \\
\text { Profile }\end{array}$ & $\begin{array}{l}\text { Number of } \\
\text { Consumers }\end{array}$ & $\begin{array}{l}\text { Percent } \\
\text { age }\end{array}$ \\
\hline Gender & & \\
\hline Male & 179 & 59.67 \\
\hline Female & 121 & 40.33 \\
\hline Age Category & & \\
\hline Below 25 Years & 17 & 5.67 \\
\hline 26- 35 Years & 77 & 25.66 \\
\hline 36-45 Years & 99 & 33.00 \\
\hline 46-55 Years & 60 & 20.00 \\
\hline Above 55 Years & 47 & 15.67 \\
\hline Education & & 10.00 \\
\hline Secondary & 30 & 17.00 \\
\hline $\begin{array}{l}\text { Higher } \\
\text { Secondary }\end{array}$ & 51 & 19.33 \\
\hline Diploma & 58 & \\
\hline
\end{tabular}

Published By:

\section{B. ENVIRONMENTAL CONCERN}

The insight of consumers on environmental concern is given in Table-2.

Table-2. Environmental Concern

\begin{tabular}{|l|l|l|}
\hline Environmental Concern & Mean & $\begin{array}{l}\text { Standar } \\
\text { d } \\
\text { Deviatio } \\
\text { n }\end{array}$ \\
\hline $\begin{array}{l}\text { I am living harmoniously with natural } \\
\text { environment }\end{array}$ & 3.29 & 1.28 \\
\hline $\begin{array}{l}\text { I am worrying about pollution of } \\
\text { environment }\end{array}$ & 3.83 & 1.11 \\
\hline $\begin{array}{l}\text { I am having right to modify character of } \\
\text { environment }\end{array}$ & 3.38 & 1.24 \\
\hline $\begin{array}{l}\text { I am concerning on degradation of } \\
\text { environment }\end{array}$ & 3.77 & 1.21 \\
\hline $\begin{array}{l}\text { I am enthusiastically involving in } \\
\text { conservation of environment }\end{array}$ & 3.35 & 1.37 \\
\hline
\end{tabular}

The consumers are agreed with they are worrying about pollution of environment and they are concerning on degradation of environment, whereas, they are neutral with they are living harmoniously with natural environment, they are having right to modify character of environment and they are enthusiastically involving in conservation of environment. C.ENVIRONMENTAL CONCERN AND

\section{SOCIO-ECONOMIC PROFILE OF CONSUMERS}

To scrutinize difference amongst environmental concern and socio-economic profile of consumers, t-test and ANOVA (Analysis of Variance) test are used and the results are given in Table-3. 
Table-3. Difference amongst Environmental Concern and Socio-Economic Profile of Consumers

\begin{tabular}{|l|l|l|}
\hline Particulars & $\begin{array}{l}\text { t-Value / } \\
\text { F-Value }\end{array}$ & Sig. \\
\hline $\begin{array}{l}\text { Gender and Environmental } \\
\text { Concern }\end{array}$ & $\begin{array}{l}5.461^{* *} \\
(\mathrm{t}-\mathrm{value})\end{array}$ & .000 \\
\hline $\begin{array}{l}\text { Age Category and Environmental } \\
\text { Concern }\end{array}$ & $\begin{array}{l}9.513^{* *} \\
(\mathrm{~F}-\text { Value) }\end{array}$ & .000 \\
\hline $\begin{array}{l}\text { Education and Environmental } \\
\text { Concern }\end{array}$ & $\begin{array}{l}5.648^{* *} \\
(\mathrm{~F}-\text { Value) }\end{array}$ & .000 \\
\hline $\begin{array}{l}\text { Monthly Income and } \\
\text { Environmental Concern }\end{array}$ & $\begin{array}{l}6.600^{* *} \\
(\mathrm{~F}-\text { Value) }\end{array}$ & .000 \\
\hline $\begin{array}{l}\text { Marital Status and Environmental } \\
\text { Concern }\end{array}$ & $\begin{array}{l}5.506^{* *} \\
(\mathrm{t}-\mathrm{value})\end{array}$ & .000 \\
\hline $\begin{array}{l}\text { Type of Family and } \\
\text { Environmental Concern }\end{array}$ & $\begin{array}{l}5.540^{* *} \\
(\mathrm{t}-\mathrm{value})\end{array}$ & .000 \\
**agnificant at 1 \% level &
\end{tabular}

The t-values and F-values demonstrate that significant socio-economic profile of consumers. Consequently, the null hypothesis is not accepted.

\section{ENVIRONMENTAL ATTITUDE}

The insight of consumers on environmental attitude is given in Table-4.

Table-4. Environmental Attitude

\begin{tabular}{|l|l|l|}
\hline Environmental Attitude & $\begin{array}{l}\text { Mea } \\
\text { n }\end{array}$ & $\begin{array}{l}\text { Standard } \\
\text { Deviation }\end{array}$ \\
\hline $\begin{array}{l}\text { Protection of environment is } \\
\text { necessary }\end{array}$ & 3.92 & 1.05 \\
\hline $\begin{array}{l}\text { Effective measures are needed to } \\
\text { protect environment }\end{array}$ & 3.88 & 1.03 \\
\hline $\begin{array}{l}\text { It is essential to promote eco-friendly } \\
\text { living }\end{array}$ & 3.85 & 1.04 \\
\hline $\begin{array}{l}\text { Environmental protection is not my } \\
\text { responsibility protection of is }\end{array}$ & 3.25 & 1.09 \\
\hline $\begin{array}{l}\text { Environmental } \\
\text { valueless }\end{array}$ & 3.33 & 1.06 \\
\hline
\end{tabular}

The consumers are agreed with protection of environment is necessary, effective measures are needed to protect environment and it is essential to promote eco-friendly living, whereas, they are neutral with environmental protection is not their responsibilities and environmental protection of is valueless.

\section{E. Environmental Attitude And Socio-Economic Profile Of}

\section{Consumers}

To inspect difference amongst environmental attitude and socio-economic profile of consumers, t-test and ANOVA (Analysis of Variance) test are done and the results are given in Table-5.

Table-5. Difference amongst Environmental Attitude and Socio-Economic Profile of Consumers

\begin{tabular}{|l|l|l|}
\hline Particulars & $\begin{array}{l}\text { t-Value / } \\
\text { F-Value }\end{array}$ & Sig. \\
\hline $\begin{array}{l}\text { Gender and Environmental } \\
\text { Attitude }\end{array}$ & $\begin{array}{l}4.867^{* *} \\
\text { (t-value) }\end{array}$ & .000 \\
\hline $\begin{array}{l}\text { Age Category and } \\
\text { Environmental Attitude }\end{array}$ & $\begin{array}{l}7.669^{* *} \\
(\mathrm{~F}-\text { Value) }\end{array}$ & .000 \\
\hline $\begin{array}{l}\text { Education and Environmental } \\
\text { Attitude }\end{array}$ & $\begin{array}{l}6.771^{* *} \\
\text { (F-Value) }\end{array}$ & .000 \\
\hline Monthly Income and & $6.875^{* *}$ & .000 \\
\hline
\end{tabular}
difference exit in environmental concern amongst

\begin{tabular}{|l|l|l|}
\hline Environmental Attitude & (F-Value) & \\
\hline $\begin{array}{l}\text { Marital Status and } \\
\text { Environmental Attitude }\end{array}$ & $\begin{array}{l}4.768^{* *} \\
\text { (t-value) }\end{array}$ & .000 \\
\hline $\begin{array}{l}\text { Type of Family and } \\
\text { Environmental Attitude }\end{array}$ & $\begin{array}{l}4.564^{* *} \\
\text { (t-value) }\end{array}$ & .000 \\
\hline
\end{tabular}

** Significant at $1 \%$ level

The t-values and F-values exhibit that significant difference exit in environmental attitude amongst socio-economic profile of consumers. Consequently, the null hypothesis is not accepted.

\section{F. ENVIRONMENTAL RESPONSIBILITY}

The insight of consumers on environmental responsibility is given in Table-6.

Table-6. Environmental Responsibility

\begin{tabular}{|l|l|l|}
\hline Environmental Responsibility & Mean & $\begin{array}{l}\text { Standard } \\
\text { Deviation }\end{array}$ \\
\hline $\begin{array}{l}\text { I have high responsibility to protect } \\
\text { environment }\end{array}$ & 3.31 & 1.09 \\
\hline $\begin{array}{l}\text { Environment protection starts from } \\
\text { me }\end{array}$ & 3.90 & 1.06 \\
\hline $\begin{array}{l}\text { I am very eager to involve in } \\
\text { activities to protect environment }\end{array}$ & 3.94 & 1.01 \\
\hline $\begin{array}{l}\text { I bear responsibility for protecting } \\
\text { environment since my childhood }\end{array}$ & 3.37 & 1.03 \\
\hline $\begin{array}{l}\text { It is the responsibility of government } \\
\text { to protect environment }\end{array}$ & 3.28 & 1.02 \\
\hline
\end{tabular}

The consumers are agreed with environment protection starts from them and they are very eager to involve in activities to protect environment, whereas, they are neutral with they have high responsibility to protect environment, they bear responsibility for protecting environment since their childhood and it is the responsibility of government to protect environment.

\section{G. ENVIRONMENTAL RESPONSIBILITY}

AND

\section{SOCIO-ECONOMIC PROFILE OF CONSUMERS}

To check difference amongst environmental responsibility and socio-economic profile of consumers, t-test and ANOVA (Analysis of Variance) test are carried out and the results are given in Table-7.

Table-7. Difference amongst Environmental Responsibility and Socio-Economic Profile of Consumers

\begin{tabular}{|l|l|l|}
\hline Particulars & $\begin{array}{l}\text { t-Value / } \\
\text { F-Value }\end{array}$ & Sig. \\
\hline $\begin{array}{l}\text { Gender and Environmental } \\
\text { Responsibility }\end{array}$ & $\begin{array}{l}4.501^{* *} \\
\text { (t-value) }\end{array}$ & .000 \\
\hline $\begin{array}{l}\text { Age Category and } \\
\text { Environmental Responsibility }\end{array}$ & $\begin{array}{l}5.922^{* *} \\
(\mathrm{~F}-\text { Value) }\end{array}$ & .000 \\
\hline $\begin{array}{l}\text { Education and Environmental } \\
\text { Responsibility }\end{array}$ & $\begin{array}{l}16.120^{* *} \\
(\mathrm{~F}-\text { Value) }\end{array}$ & .000 \\
\hline $\begin{array}{l}\text { Monthly Income and } \\
\text { Environmental Responsibility }\end{array}$ & $\begin{array}{l}9.403^{* *} \\
(\mathrm{~F}-\text { Value) }\end{array}$ & .000 \\
\hline $\begin{array}{l}\text { Marital Status and } \\
\text { Environmental Responsibility }\end{array}$ & $\begin{array}{l}4.193^{* *} \\
(\mathrm{t}-\mathrm{value})\end{array}$ & .000 \\
\hline
\end{tabular}

Published By: 


\begin{tabular}{|l|l|c|}
\hline $\begin{array}{l}\text { Type of Family and } \\
\text { Environmental Responsibility }\end{array}$ & $\begin{array}{l}5.095^{* *} \\
\text { (t-value) }\end{array}$ & .000 \\
\hline
\end{tabular}

Significant at $1 \%$ level

The t-values and F-values display that significant difference exit in environmental responsibility amongst socio-economic profile of consumers. Consequently, the null hypothesis is not accepted.

\section{H. RELATION AMONGST ENVIRONMENTAL} CONCERN, ATTITUDE AND RESPONSIBILITY AND

\section{GREEN PURCHASING BEHAVIOUR OF CONSUMERS}

The relation amongst environmental concern, attitude and responsibility and green purchasing behaviour of consumers was studied by using correlation analysis and the results are given in Table- 8 .

Table-8. Relation amongst Environmental Concern, Attitude and Responsibility and Green Purchasing Behaviour of Consumers

\begin{tabular}{|l|l|l|l|l|}
\hline $\begin{array}{l}\text { Particu } \\
\text { lars }\end{array}$ & $\begin{array}{l}\text { Enviro } \\
\text { nmenta } \\
\text { l } \\
\text { Concer } \\
\text { n }\end{array}$ & $\begin{array}{l}\text { Environ } \\
\text { mental } \\
\text { Attitude }\end{array}$ & $\begin{array}{l}\text { Environmenta } \\
\text { l }\end{array}$ & $\begin{array}{l}\text { Green } \\
\text { Purcha } \\
\text { sing } \\
\text { Behavi } \\
\text { our }\end{array}$ \\
\hline $\begin{array}{l}\text { Environ } \\
\text { mental } \\
\text { Concern }\end{array}$ & $\mathbf{1 . 0 0}$ & & & \\
\hline $\begin{array}{l}\text { Environ } \\
\text { mental } \\
\text { Attitude }\end{array}$ & $0.28^{* *}$ & $\mathbf{1 . 0 0}$ & $\mathbf{1 . 0 0}$ & \\
\hline $\begin{array}{l}\text { Environ } \\
\text { mental } \\
\text { Respons } \\
\text { ibility }\end{array}$ & $0.24^{* *}$ & $0.31^{* *}$ & & \\
\hline $\begin{array}{l}\text { Green } \\
\text { Purchas } \\
\text { ing } \\
\text { Behavio } \\
\text { ur }\end{array}$ & $0.53^{* *}$ & $0.55^{* *}$ & $0.57^{* *}$ & $\mathbf{1 . 0 0}$ \\
\hline
\end{tabular}

*** Significant at $1 \%$ level

The correlation co-efficient amongst environmental concern and green purchasing behaviour of consumers is 0.53 , which is positively and moderately interrelated. The correlation co-efficient amongst environmental attitude and green purchasing behaviour of consumers is 0.55 , that is positively and moderately related. The correlation co-efficient amongst environmental responsibility and green purchasing behaviour of consumers is 0.57 , it is positively and moderately associated. As an outcome, the null hypothesis is not accepted.

\section{CONCLUSION}

The findings of this study make clear that significant difference prevails amongst environmental concern, environmental attitude and environmental responsibility and socio-economic profile of consumers. Environmental concern, environmental attitude and environmental responsibility have positive, moderate and significant relation with green purchasing behaviour of consumers. Therefore, consumers must live harmoniously with natural environment and they should not make any attempts to modify character of environment and consumers must enthusiastically involve in conservation of environment. Further, Government and environmental organizations and non government organizations should make consumers to realize their responsibilities and necessity for protection of environment through various awareness programmes and campaigns and incentives. In addition, to encourage green purchasing amongst consumers, producers and marketers must inform them effectively need for conservation of environment through their promotional and marketing strategies and programmes.

\section{REFERENCES:}

[1] Abdul Wahid, N., Rahbar, E., \& Shyan, T. (2011). Factors influencing the green purchase behaviour of Penang environmental volunteer. International Business Management, 5(1), 38-49.

[2] Aman, A.L., Harun,A., \& Hussein, Z. (2012). The influence of environmental knowledge and concern on green purchase intention the role of attitude as a mediating variable. British Journal of Arts and Social Sciences, 7(2), 145-167.

[3] Chung-Te Ting, Chi-Ming Hsieh, Hsiao-Ping Chang, \& Han-Shen Chen. (2019). Environmental consciousness and green customer behavior: The moderating roles of incentive mechanisms. Sustainability, 11, $1-16$.

[4] Cornelissen, G., Pandelaere, M., Warlop, L., \& Dewitte, S. (2008). Positive cueing: Promoting sustainable consumer behaviour by cueing common environmental behaviours as environmental, International Journal of Research in Marketing, 12(1), 46-54.

[5] Dagher, G., \& Itani, O. (2012). The influence of environmental attitude, environmental concern and social influence on green purchasing behaviour. Review of Business Research, 12(2), 104-111.

[6] Grace K Dagher, Omar Itani, \& Abdul Nasser Kassar. (2015). The impact of environment concern and attitude on green purchasing behavior: Gender as the moderator. Contemporary Management Research, 11(2), 179-206.

[7] Han, H., Hsu, L., \& Lee, J. (2009). Empirical investigation of the roles of attitudes toward green behaviours, overall image, gender, and age in hotel customers' eco-friendly decision making process. International Journal of Hospitality Management, 28(4), 519-528.

[8] Hessam Zand Hessami, \& Parisa Yousefi. (2013). Investigation of major factors influencing green purchasing behavior: Interactive approach. European Online Journal of Natural and Social Sciences, 2(4), 584-596.

[9] Kamonthip Maichum, Surakiat Parichatnon, \& Ke-Chung Peng. (2017).The influence of environmental concern and environmental attitude on purchase intention towards green products: A case study of young consumers in Thailand. International Journal of Business Marketing and Management, 2(3), 1-8.

[10] Lee, Y.K., Kim, S., Kim, M.S., \& Choi, J.G. (2014). Antecedents and interrelationships of three types of pro-environmental behavior. Journal of Business Research, 67(10), 2097-2105.

[11] Papadopoulos, I., Karagouni, G., Trigkas, M., \& EvanthiaPlatogianni, I. (2010). Green marketing, European Medieval Journal of Business, 5(2), 166-190.

[12] Pratiwi Ni Putu Deviary Kusuma, \& Sulhaini Rinuastuti Baiq Handayani. (2018). The effect of environmental knowledge, green advertising and environmental attitude toward green purchase intention. RJOAS, 6(78), 95-105.

[13] Rahbar, E., \& Wahid, N. A. (2011). Investigation of green marketing tools' effect on consumers' purchase behavior. Business Strategy Series, 12 (2), 73-83.

[14] Vicente Molina, M. A., Fernandez Sainz, A., \& Izagirre Olaizola, J. (2013). Environmental knowledge and other variables affecting pro-environmental behaviour: Comparison of university students from emerging and advanced countries. Journal of Cleaner Production, 61, $130-138$.

\section{Published By:}


[15] Walailak Atthirawong, \& Wariya Panprung. (2017). A study on the consumers' buying behavior towards green products in Bangkok. International Journal of Management and Applied Science, 3(11), 26-31.

[16] Zakia Binte Jamal, Sohel Islam, \& Promotosh Barua. (2016). Analyzing factors that affect green purchase behavior: From the context of Bangladeshi consumers, Journal of Economics, Business and Management, 4(10), 611-617.

\section{AUTHORS PROFILE}

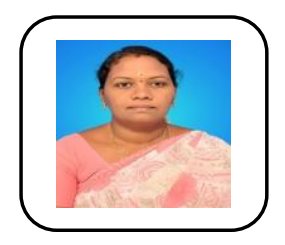

She is Dr.S.RANI M.Com M.Phil., B.Ed., MBA, PGDCA, Ph.D. She has published two of Scopus indexed journals, one of UGC listed journal, and she got the Nehru Best Faculty Award, Exclusively for Commerce, Management and Computer Applications,

Nehru Group of Institutions, Coimbatore, she has published 9 papers in various journals and she has published around 30 papers in various National \& International conferences and Seminars. She has attended Seven Workshops \& Six Faculty Development Programs. She has Chairperson on the theme Building Inclusive Leadership Ecosystem for Global Business in an International Conference organized by NIT Coimbatore. Acted as a Chairperson of Board of Studies in Department of Commerce in Kalasalingam Academy of Research and Education (Kalasalingam University) at Krishnankoil. She has Advisory Board Member in Nehru Institute of Technology in Coimbatore. She has acted as the Head of the Department Of Commerce at Kalasalingam Academy Of Research And Education from 2015 to 2018. She has State Organizer in Consumer Club State Organizer South Indian Consumer \& People Rights Protection Council and She has a Life time Member of Indian Accounting Association, Salem. 